\title{
Research on the Relationship between Corporate Social Responsibility and Financial Performance Based on Grey Correlation Analysis: Taking the Smartphone Company as an Example
}

\author{
Bingjun Li, Xiaolu Li ${ }^{*}$ \\ College of Information and Management Science, Henan Agricultural University, Zhengzhou, China \\ Email: zzlbjun@163.com, ^xiaolu_lil@163.com
}

How to cite this paper: Li, B.J. and Li, X.L. (2018) Research on the Relationship between Corporate Social Responsibility and Financial Performance Based on Grey Correlation Analysis: Taking the Smartphone Company as an Example. Open Journal of Applied Sciences, 8, 431-440. https://doi.org/10.4236/ojapps.2018.89033

Received: July 2, 2018

Accepted: September 27, 2018

Published: September 30, 2018

Copyright (๑) 2018 by authors and Scientific Research Publishing Inc. This work is licensed under the Creative Commons Attribution International License (CC BY 4.0).

http://creativecommons.org/licenses/by/4.0/

(c) (i) Open Access

\begin{abstract}
In order to explore the relationship between the corporate social responsibility (CSR) and financial performance in different CSR cultures, this paper respectively takes four representative smartphone companies in China, the United States, Japan and Korea as research objects, that is Huawei, Apple, Sony and Samsung smartphone companies. Then, dividing the CSR into five dimensions i.e. shareholder, customer, supplier, technology innovation and government and establishing the grey correlation model to empirically analyze the relationship between CSR and financial performance. The results indicate that for HUAWEI, the CSR performance in shareholder, customer and technology innovation have greater impact on its financial performance; for Apple, the CSR performance in shareholder, technology innovation and customer has greater impact on its financial performance; for SONY, the CSR performance in technology innovation, customer and shareholder has greater impact on its financial performance; for Samsung, the CSR performance in technology innovation, government and shareholder has greater impact on its financial performance.
\end{abstract}

\section{Keywords}

Corporate Social Responsibility, Smart Phone Company, Grey Correlation Analysis, Financial Performance

\section{Introduction}

In 1979, Carroll [1] defined the corporate social responsibility (CSR) as the sum 
of the economic, legal, ethical and philanthropic responsibilities fulfilled by the company over a certain period of time. This definition has attracted the attention of scholars and has been widely accepted. Company is the organization that exists for profit. Therefore, since China introduced the definition of CSR in 1980s, the impact of it on financial performance has become the focus of Chinese academic circles.

$\mathrm{Xu}$ et al. [2] first empirically studied the relationship between CSR and financial performance. And the 2001-2006 data of 64 A-share companies listed on the Shanghai Stock Exchange in major consumer industries were selected as the sample to research. The results show that CSR performance will bring long-term excellent financial performance, and the current CSR performance has greater impact on current financial performance. Yang et al. [3] conducted the research by comparing the large companies with SMEs. The large companies were the top 500 Chinese companies listed in Shanghai and Shenzhen in 2012, the SMEs were the company listed on SMEs board. The results indicate that whether it is a large company or SEMs, CSR will not cause the deterioration of its short-term financial performance. As for long-term financial performance, the CSR performance of large company has positive impact on it, but the SEMs are negative relationship. Wang et al. [4] regarded the Chinese commercial listed companies from 2011-2013 as research objects to conduct an analysis. The results show that the company's good performance in terms of shareholders and creditors can significantly improve financial performance, and fulfilling its responsibilities to customers can also significantly improve corporate performance in the long run. Company actively undertakes CSR can improve the company's profitability and in turn has a positive impact on financial performance (Qi et al. [5]; Rodriguez [6]; Torugsa et al. [7]; Ahamed et al. [8]; Zhu [9]; Yin et al. [10]). However, some scholars believe that there is a negative relationship between the CSR and financial performance. That is, the better the CSR performance, the weaker profitability. And the corresponding costs of fulfilling CSR may lead to the company at a competitive disadvantage, which is not conducive to the long-term development and then in turn impairs its financial performance (Robert [11]; Bansal [12]). Meanwhile, there are some scholars demonstrated that it is no relationship between CSR and financial performance. Even if a company fulfills its social responsibilities, it will not make the financial performance better. Dou [13] empirically analyzed the panel data of 955 listed companies in Shanghai and Shenzhen during 2009-2013, and the results show that the positive impact of CSR on financial performance is not obvious. Chen [14] selected "China Top 100 Corporate Social Responsibility Development Index" from 2009 to 2012 to analyze the impact of CSR on financial performance of China's state-owned and private listed companies. The results show that comprehensive social responsibility has no significant impact on financial performance.

From the studies of the above scholars, it can be found that the existing researches mostly use the relevant data of all listed companies within a certain 
number of years to analyze the relationship between CSR and financial performance, whereas few scholars study the relationship between them in a particular industry. However, the relationship between CSR and financial performance are different in different industries, and the results of the research analysis using listed companies in all industries are not necessarily applicable to each industry. Then, it is worth noting that although the listed company's published CSR report, annual financial report and other information are public and explicit, the mere use of such information to evaluate CSR performance and financial performance is still incomplete and grey. Therefore, in the empirical analysis of the relationship between CSR and financial performance, it is difficult to draw reliable conclusions without considering such grey statistics. Finally, at present, most of the samples selected for research are companies that operate under the background of Chinese CSR culture. However, with the acceleration of economic globalization, in order to provide experience for Chinese companies to find the focus of CSR fulfillment and improve its financial performance, it is necessary to analyze the companies in different countries and different CSR culture background.

Based on it, in order to enrich the research in this area, this paper selects the smartphone represent companies in the background of CSR culture in the United States, Japan, Korea and China as research objects, that is Apple, SONY, Samsung and HUAWEI. Due to the characteristics of sample data of small sample size and poor information, the grey correlation model is established to empirically analyze the relationship between CSR and financial performance based on the companies' CSR report and annual Report from 2012 to 2017.

\section{Theoretical Framework}

\subsection{The Measurement Index System of CSR and Financial Performance}

When carry out the research about CSR, most Chinese scholars would adopt two types of dimensions of CSR to reflect the CSR performance. One is the nine dimensions of CSR proposed by Xu et al. [15] through investigated 630 owners of companies, that is economic responsibility, legal responsibility, environment protection responsibility, customer-oriented responsibility, people-first responsibility, public welfare responsibility, employment responsibility, business ethics responsibility and social stability and progress responsibility. Another one is the eight dimensions of CSR in the "Chinese Corporate Social Responsibility Report" published by the Chinese Academy of Social Sciences (CASS), that is shareholder, supply chain, customer, technological innovation, management under the law, community relations, safe production and green management. Considering the reality of the limited information disclosed by the research object, the indicators are designed in accordance with the principles of integrity, feasibility, and independence. Integrity means that the selected indicators can form a unified whole without any omission. Feasibility reflects that the data of 
the selected indicators is easy to obtain, operate and analyze conveniently. Independence intends that the selected indicators should be independent of each other and cannot involve each other (Hu et al. [16]). The indicators selected with the above principles could reasonably reflect the CSR performance. Thus, according to the above principles, shareholder, customer, supplier, technological innovation and government are chose to measure the CSR performance. In order to further analysis, the rate of return on common stockholders' equity (ROE) is selected to reflect the performance of the company's responsibility to shareholder; Operating cost rate is selected to reflect the performance of the company's responsibility to customer; Account payable turnover rate is selected to reflect the performance of the company's responsibility to supplier; Research and development expenditure rate is selected to reflect the performance of the company's responsibility to technological innovation; Income tax rate is selected to reflect the performance of the company's responsibility to government; Return on total assets rate is an indicator of corporate financial performance. Details are shown in Table 1.

\subsection{Establishment a Grey Correlation Model of the Impact of CSR on Financial Performance}

For a relatively stable system, if there is a strong correlation between the two elements, the two should also reflect this correlation in the future period of time; otherwise, if the correlation between the two is not strong, this weak correlation will also remain for a period of time (Zhang et al. [17]). From the perspective of the system, the company is a relatively stable system. Based on this feature of the system, it is possible to combine CSR performance with the financial performance of the company and analyze the relationship between them. Although the company's financial annual report and other information are open and explicit, the mere use of such information to evaluate the CSR performance and financial performance is still incomplete and grey. Thus, the company could be regard as a system and the degree of the correlation between the dimensions of CSR and financial performance is analyzed with grey correlation analysis.

Grey correlation analysis is the active branch of the grey system theory. The basic thinking is to determine whether the correlation between different sequences is tight based on the geometry of the sequence curve. The fundamental idea is to convert the discrete behavior observations of the system factors into a piece-wise continuous polygonal line by linear interpolation method, and then to construct model of measuring the degree of correlation based on the geometric features of the polygonal line (Liu et al. [18]). Process is as follows.

Step 1: Determine the reference sequence and compare sequence.

Assume the dependent variable data as the reference sequence and the respective variable data as the compare sequence. In this study, the indicator that reflects the financial performance of the company is used as a reference sequence, and the indicator of CSR performance is used as a compare sequence. 
Table 1. The indicator system of CSR and financial performance.

\begin{tabular}{|c|c|c|}
\hline & & Dimensions Indicators \\
\hline \multirow{5}{*}{ CSR } & shareholder & $\begin{array}{l}\text { return on common stockholders' equity }=\text { net } \\
\text { profit/average shareholders' equity }(\mathrm{X} 1)\end{array}$ \\
\hline & customer & $\begin{array}{l}\text { operating cost rate }=\text { operating cost/operating revenue } \\
(\mathrm{X} 2)\end{array}$ \\
\hline & supplier & $\begin{array}{l}\text { account payable turnover rate }=(\text { operating cost }+ \\
\text { ending inventory-beginning inventory)/average } \\
\text { payable account }(\mathrm{X} 3)\end{array}$ \\
\hline & $\begin{array}{l}\text { technological } \\
\text { innovation }\end{array}$ & $\begin{array}{l}\text { research and development expenditure rate = research } \\
\text { and development expenditure/operating revenue }(\mathrm{X} 4)\end{array}$ \\
\hline & government & income tax rate $=$ total income tax/total profit $(\mathrm{X} 5)$ \\
\hline $\begin{array}{l}\text { Corporate financial } \\
\text { performance }\end{array}$ & $\begin{array}{l}\text { return on total } \\
\text { assets rate }\end{array}$ & $\begin{array}{l}\text { return on total assets rate }=\text { profit before tax/average } \\
\text { total assets }(\mathrm{Y})\end{array}$ \\
\hline
\end{tabular}

The reference sequence is as follows.

$$
X_{0}=\left(x_{0}(1), x_{0}(2), \cdots, x_{0}(n)\right)
$$

The compare sequence is as follows.

$$
\begin{gathered}
X_{i}=\left(x_{i}(1), x_{i}(2), \cdots, x_{i}(n)\right) \\
i=(1,2, \cdots, m)
\end{gathered}
$$

Step 2: Obtain the initial value image of each sequence.

$$
\begin{gathered}
X_{i}^{\prime}=X_{i} / x_{i}(1)=\left(x_{i}^{\prime}(1), x_{i}^{\prime}(2), \cdots, x_{i}^{\prime}(n)\right) \\
i=(0,1,2, \cdots, m)
\end{gathered}
$$

Step 3: Obtain the absolute value sequence of the difference between the corresponding components of the initial value image of $X_{0}$ and $X_{i}$.

$$
\begin{gathered}
\Delta_{i}(k)=\left|x_{0}^{\prime}(k)-x_{i}^{\prime}(k)\right| \\
\Delta_{i}=\left(\Delta_{i}(1), \Delta_{i}(2), \cdots, \Delta_{i}(n)\right) k=1,2, \cdots, n ; i=1,2, \cdots, \mathrm{m}
\end{gathered}
$$

Then obtain the maximum value $(M)$ and minimum value $(m)$ among

$$
\begin{gathered}
\Delta_{i}(k)=\left|x_{0}^{\prime}(k)-x_{i}^{\prime}(k)\right|, \quad k=1,2, \cdots, n, \quad i=1,2, \cdots, m . \\
M=\max _{i} \max _{k} \Delta_{i}(k) m=\min _{i} \min _{k} \Delta_{i}(k)
\end{gathered}
$$

Step 4: Obtain the grey correlation coefficient.

$$
\begin{gathered}
\gamma_{0 i}(k)=\frac{m+\xi M}{\Delta_{i}(k)+\xi M}, \xi \in(0,1) \\
k=1,2, \cdots, n, i=1,2, \cdots, m
\end{gathered}
$$

$\xi$ is called as discrimination coefficient and usually taken as 0.5 .

Step 5: Obtain the grey correlation degree and it is the average of the all grey correlation coefficient. 


$$
\gamma_{0 i}(k)=\frac{1}{n} \sum_{k=1}^{n} \gamma_{0 i}(k) k=1,2, \cdots, m
$$

$\gamma_{0 i}$ is the correlation degree between the reference sequence and compare sequence. The $\gamma_{0 i}$ is bigger, the correlation degree of them is bigger, and vice versa. Sort the grey correlation degree between the compare sequence that reflects the CSR performance and the reference sequence that reflects the financial performance, and then CSR behaviors could be obtained which have greater impact on company's financial performance.

\section{Empirical Analysis}

This paper regards the HUAWEI, Apple, SONY and Samsung as research objects, which HUAWEI is an unlisted company whereas the remaining three are listed companies. According to the annual financial report and annual report of the four companies from 2012-2017, the initial data of CSR and financial performance are shown in Tables 2-5.

The grey correlation analysis is conducted with the initial data from Tables 2-5. The $Y$ is regarded as the reference sequence, and the $X_{1}-X_{5}$ are regarded as the compare sequence. According to experience, the discrimination coefficient can be taken 0.5 , the data is processed according to the procedure of the grey correlation analysis. The results are shown in Table 6.

Table 2. Initial data of indicators of CSR and financial performance of HUAWEI.

\begin{tabular}{|c|c|c|c|c|c|c|}
\hline & $\begin{array}{l}\text { return on } \\
\text { common } \\
\text { stockholders' } \\
\text { equity rate }\end{array}$ & $\begin{array}{l}\text { operating } \\
\text { cost rate }\end{array}$ & $\begin{array}{l}\text { account payable } \\
\text { turnover rate }\end{array}$ & $\begin{array}{c}\text { research and } \\
\text { development } \\
\text { expenditure } \\
\text { rate }\end{array}$ & $\begin{array}{l}\text { income } \\
\text { tax rate }\end{array}$ & $\begin{array}{c}\text { return on } \\
\text { total assets } \\
\text { rate }\end{array}$ \\
\hline & $\mathbf{X}_{1}$ & $\mathbf{X}_{2}$ & $\mathbf{X}_{3}$ & $\mathbf{X}_{4}$ & $\mathbf{X}_{5}$ & $\mathrm{Y}$ \\
\hline 2012 & 0.218 & 0.602 & 4.259 & 0.137 & 0.150 & 0.090 \\
\hline 2013 & 0.260 & 0.590 & 4.433 & 0.128 & 0.165 & 0.114 \\
\hline 2014 & 0.299 & 0.558 & 4.773 & 0.142 & 0.157 & 0.122 \\
\hline 2015 & 0.337 & 0.583 & 4.617 & 0.151 & 0.121 & 0.123 \\
\hline 2016 & 0.286 & 0.597 & 4.906 & 0.146 & 0.159 & 0.108 \\
\hline 2017 & 0.301 & 0.605 & 5.056 & 0.149 & 0.155 & 0.118 \\
\hline
\end{tabular}

Table 3. Initial data of indicators of CSR and financial performance of Apple.

\begin{tabular}{|c|c|c|c|c|c|c|}
\hline & $\begin{array}{l}\text { return on } \\
\text { common } \\
\text { stockholders' } \\
\text { equity rate }\end{array}$ & $\begin{array}{l}\text { operating } \\
\text { cost rate }\end{array}$ & $\begin{array}{l}\text { account payable } \\
\text { turnover rate }\end{array}$ & $\begin{array}{l}\text { research and } \\
\text { development } \\
\text { expenditure } \\
\text { rate }\end{array}$ & $\begin{array}{l}\text { income } \\
\text { tax rate }\end{array}$ & $\begin{array}{c}\text { return on } \\
\text { total assets } \\
\text { rate }\end{array}$ \\
\hline & $\mathrm{X}_{1}$ & $\mathrm{X}_{2}$ & $\mathrm{X}_{3}$ & $\mathrm{X}_{4}$ & $\mathrm{X}_{5}$ & $\mathrm{Y}$ \\
\hline 2012 & 0.428 & 0.561 & 4.907 & 0.022 & 0.252 & 0.381 \\
\hline 2013 & 0.306 & 0.624 & 4.941 & 0.026 & 0.262 & 0.262 \\
\hline 2014 & 0.336 & 0.614 & 4.285 & 0.033 & 0.261 & 0.244 \\
\hline
\end{tabular}




\section{Continued}

\begin{tabular}{lllllll}
\hline 2015 & 0.462 & 0.599 & 4.273 & 0.035 & 0.264 & 0.278 \\
2016 & 0.369 & 0.609 & 3.604 & 0.047 & 0.256 & 0.201 \\
2017 & 0.369 & 0.615 & 3.330 & 0.051 & 0.246 & 0.184 \\
\hline
\end{tabular}

Table 4. Initial data of indicators of CSR and financial performance of SONY.

\begin{tabular}{ccccccc}
\hline & $\begin{array}{c}\text { return on } \\
\text { common } \\
\text { stockholders' } \\
\text { equity rate }\end{array}$ & $\begin{array}{c}\text { operating } \\
\text { cost rate }\end{array}$ & $\begin{array}{c}\text { account payable } \\
\text { turnover rate }\end{array}$ & $\begin{array}{c}\text { research } \\
\text { and } \\
\text { development } \\
\text { expenditure rate }\end{array}$ & $\begin{array}{c}\text { income } \\
\text { tax rate }\end{array}$ & $\begin{array}{c}\text { return on } \\
\text { total assets } \\
\text { rate }\end{array}$ \\
\hline 2012 & -0.146 & 0.676 & 5.657 & $\mathrm{X}_{4}$ & $\mathrm{X}_{5}$ & $\mathrm{Y}$ \\
2013 & 0.039 & 0.660 & 6.746 & 0.073 & -3.790 & -0.006 \\
2014 & -0.025 & 0.662 & 8.038 & 0.069 & 0.580 & 0.018 \\
2015 & -0.017 & 0.642 & 7.800 & 0.060 & 3.674 & 0.002 \\
2016 & 0.069 & 0.637 & 8.839 & 0.057 & 2.233 & 0.003 \\
2017 & 0.041 & 0.625 & 8.637 & 0.055 & 0.311 & 0.019 \\
\hline
\end{tabular}

Table 5. Initial data of indicators of CSR and financial performance of Samsung.

\begin{tabular}{ccccccc}
\hline & $\begin{array}{c}\text { return on } \\
\text { common } \\
\text { stockholders } \\
\text { equity rate }\end{array}$ & $\begin{array}{c}\text { operating } \\
\text { cost rate }\end{array}$ & $\begin{array}{c}\text { account } \\
\text { payable } \\
\text { turnover rate }\end{array}$ & $\begin{array}{c}\text { research and } \\
\text { development income tax return on total } \\
\text { expenditure } \\
\text { rate }\end{array}$ & rate & assets rate \\
\hline 2012 & 0.214 & 0.630 & 7.270 & 0.059 & 0.203 & 0.178 \\
2013 & 0.224 & 0.602 & 8.057 & 0.064 & 0.206 & 0.194 \\
2014 & 0.148 & 0.622 & 9.900 & 0.070 & 0.161 & 0.125 \\
2015 & 0.112 & 0.615 & 17.725 & 0.068 & 0.266 & 0.110 \\
2016 & 0.125 & 0.596 & 18.910 & 0.070 & 0.260 & 0.122 \\
2017 & 0.210 & 0.540 & 17.460 & 0.068 & 0.249 & 0.199 \\
\hline
\end{tabular}

Table 6. The grey correlation degree and grey correlation order between CSR indicators and financial performance indicators.

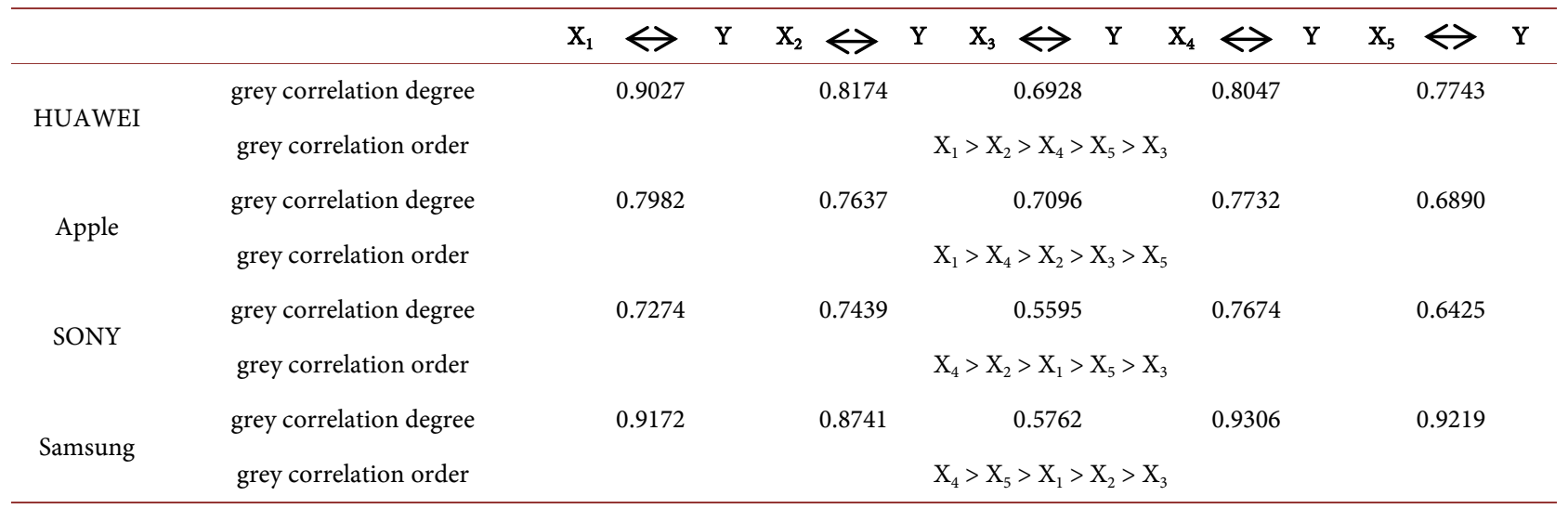


In Table 6, all grey correlation degrees are greater than 0.5 , indicating that the five CSR measurement indicators have a greater impact on return on total assets rate in these four companies. In addition, the results also reflect the impact of CSR behaviors on financial performance, and specific to disparate company, influence degree each are not identical. For HUAWEI, the impact of CSR behaviors on financial performance is ranked as follows: shareholder > customer $>$ technological innovation > government > supplier; For Apple, the impact of CSR behaviors on financial performance is ranked as follows: shareholder $>$ technological innovation > customer > supplier > government; For SONY, the impact of CSR behaviors on financial performance is ranked as follows: technological innovation $>$ customer $>$ shareholder $>$ government $>$ supplier; For Samaung, the impact of CSR behaviors on financial performance is ranked as follows: technological innovation $>$ government $>$ shareholder $>$ customer $>$ supplier. From the above ranking, the top three of the impact of CSR behaviors on financial performance are taken for research and analysis. It can be found that for HUAWEI, the top three are shareholder, customer and technological innovation; for Apple, the top three are shareholder, technological innovation and customer; for SONY, the top three are technological innovation, customer and shareholder; for Samsung, the top three are technological innovation, government and shareholder. The study finds that in the context of different CSR cultures, of the five CSR dimensions selected in this paper, the greatest impact on financial performance is shareholder and technology innovation, and secondly, from the analysis results of HUAWEI, Apple and SONY, customer is also among the top three, but for Samsung, the CSR performance in government is greater than that in customer. Some possible reasons for the slightly different results of Samsung's analysis are as follows. Firstly, in the Korean smart phone market, Samsung, as a well-known domestic mobile phone company in Korea, has the highest market share of smart phones and is close to monopoly companies. Therefore, improving its CSR performance in customer does not necessarily enhance its competitiveness and thus improve its financial performance. This is determined by the characteristics of the Korean smart phone market. Secondly, since the CSR was introduced into Korean, it had attracted the managers of the company and public attention, and then the Korean government issued relevant charters to regulate the company's CSR behaviors. And until now, the Korean government's environmental protection department, the National Honor Society and the Economic Commission are all continuing to implement CSR activities. That has a greater influence for the companies to fulfill the responsibility to government. All in all, for HUAWEI, Apple and SONY, in order to improve their financial performance, they must pay attention to the CSR performance in shareholder, customer and technological innovation; For Samsung, it should focus on CSR performance in technological innovation, government and shareholder. The results of this research are consistent with the characteristics of the research objects, demonstrating the reliability of the results. 


\section{Conclusion}

China's corporate social responsibility started late, and the theory and practice are still in the process of exploration. Therefore, we can learn from the development experience of other countries and combine Chinese characteristics to provide a theoretical basis for the company in China to plan CSR activities. Thus, this research takes four representative smartphone companies under the background of CSR culture in China, the United States, Japan and Korea as the research objects. Considering the characteristics of the research data of small sample and poor information, the grey correlation analysis model is established to empirically analyze the impact of CSR on financial performance. The results of this study indicate that due to the different stages of CSR in the countries where the four companies are located, the five dimensions of CSR have different impacts on financial performance among four companies, but overall, the results are consistent. Actively carrying on the CSR in shareholder, customer and technological innovation can help improve the financial performance. Meanwhile, although the CSR performance in shareholder, customer and technology innovation have different impacts on financial performance in companies with different CSR culture backgrounds, their overall performance is greater than other dimensions of CSR. What's more, other smartphone companies or similar companies can use this result as a reference to plan CSR activities to improve financial performance.

\section{Acknowledgements}

The authors are grateful to anonymous referees for their helpful and constructive comments on this paper. This study is supported by Soft-science Foundation of the Education Department of Henan Province (18B630008); Soft-science Foundation of Henan Province (172400410015).

\section{Conflicts of Interest}

The authors declare no conflicts of interest regarding the publication of this paper.

\section{References}

[1] Carroll, A.B. (1979) A Three Dimensional Conceptual Model of Corporate Social Performance. The Academy of Management Review, 4, 497-505. https://doi.org/10.5465/amr.1979.4498296

[2] Xu, G. and Zhang, R. (2007) Research on the Relationship between Corporate Social Responsibility and Financial Performance. Communication of Finance and Accounting (Academy Version), No. 12, 70-73.

[3] Yang, W. and Yang, S. (2016) An Empirical Study on the Relationship between Corporate Social Responsibility and Financial Performance under the Chinese Context-Based on the Contrastive Analysis of Large, Small and Medium-Size Listed Companies. Chinese Journal of Management Science, 24, 143-150.

[4] Wang, C. and Liang, H. (2016) Research on the Relevance of Corporate Social Re- 
sponsibility and Financial Performance: A Case Study of Commercial Listed Companies. Friends of Accounting, No. 04, 80-83.

[5] Qi, G.Y., Zeng, S.X., Shi, J.J., Meng, X.H., Lin, H. and Yang, Q.X. (2014) Revisiting the Relationship between Environmental and Financial Performance in Chinese Industry. Journal of Environmental Management, 145, 349.

https://doi.org/10.1016/j.jenvman.2014.07.010

[6] Rodriguez, M.D.M.M. (2014) Corporate Social Responsibility and Financial Performance: A Meta-Analysis. Spanish Journal of Finance \& Accounting, 43, 193.

[7] Torugsa, N.A., O’Donohue, W. and Hecker, R. (2012) Capabilities, Proactive CSR and Financial Performance in SMEs: Empirical Evidence from an Australian Manufacturing Industry Sector. Journal of Business Ethics, 109, 483-500.

https://doi.org/10.1007/s10551-011-1141-1

[8] Ahamed, W.S.W., Almsafir, M.K. and Al-Smadi, A.W. (2014) Does Corporate Social Responsibility Lead to Improve in Firm Financial Performance? Evidence from Malaysia. International Journal of Economics and Finance, 6, 126.

[9] Zhu, S. (2011) Corporate Social Responsibility, Market Evaluation and Informativeness of Accounting Earnings. Accounting Research, No. 11, 27-34.

[10] Yin, K., Liu, X. and Chen, H. (2014) Study on the Relationship between Corporate Social Responsibility and Financial Performance from the Endogenous Perspective-Evidence from Chinese Listed Companies. China Soft Science, No. 6, 98-108.

[11] Robert, W.R., Karim, K.E., Aleksanyan, M. and Wu, C. (2014) An Examination of the Relationship between Corporate Social Responsibility and Financial Performance: The Case of Chinese State-Owned Enterprises. Advances in Environmental Accounting \& Management, No. 5, 1-22. https://doi.org/10.1108/S1479-359820140000005001

[12] Bansal, P. (2004) Evolving Sustainably: A Longitudinal Study of Corporate Sustainable Development. Strategic Management Journal, 20, 197-218.

[13] Dou, X. (2015) The Lagging Effects of the Influence of Corporate Social Responsibility on Corporate Financial Performance-Empirical Analysis Based on the Panel Data of Chinese Listed Companies. Industrial Economics Research, No. 3, 74-81.

[14] Chen, X. (2014) Moderated Mediating Effect of Corporate Social Responsibility on Financial Performance-Empirical Evidence Based on the CSR Development Index of Top 100 Firms in China. Journal of Shanxi University of Finance and Economics, 3, 101-109.

[15] Xu, S. and Yang, R. (2007) A Conclusive Analysis within the Conceptive Scope of Corporate Social Responsibility. China Industrial Economics, No. 5, 71-79.

[16] Hu, Z., Zhang, A. and Ma, T. (2014) Research on the Construction and Application of Corporate Social Responsibility Based on Grey Relational Analysis-Taking Listed Companies in Food and Beverage Industry as an Example. Commercial Accounting, No. 17, 45-65.

[17] Zhang, H. and Song, Q. (2009) Application of Grey Relational Analysis in Determining High-Quality Customer Assets. Productivity Research, No. 12, 146-148.

[18] Liu, S., Cai, H., Yang, Y. and Cao, Y. (2013) Advance in Grey Incidence Analysis Modelling. Systems Engineering-Theory \& Practice, 33, 2041-2046. 